\title{
SPATIO-TEMPORAL DYNAMICS IN LAND USE AND HABITAT FRAGMENTATION WITHIN A PROTECTED AREA DEDICATED TO TOURISM IN A SUDANIAN SAVANNA OF WEST AFRICA
}

\author{
KANGBÉNI DIMOBE ${ }^{* 1,2,3,4}$, DETHARDT GOETZE ${ }^{3}$, AMADÉ OUÉDRAOGO ${ }^{2}$, \\ GERALD FORKUOR $^{4}$, KPÉRKOUMA WALA ${ }^{1}$, STEFAN POREMBSKI $^{3}$ \\ AND ADJIMA THIOMBIANO ${ }^{2}$
}

${ }^{1}$ Laboratory of Botany and Plant Ecology, Department of Botany, Faculty of Sciences, University of Lomé, Po. Box. 1515, Lomé, Togo.

${ }^{2}$ Laboratory of Plant Biology and Ecology, UFR-SVT, University Ouaga I Joseph Ki-Zerbo, 03 Po. Box: 7021Ouagadougou 03, Burkina Faso.

${ }^{3}$ Institute of Biological Sciences, Department of Botany, University of Rostock, D-18051

Rostock, Germany

${ }^{4}$ Competency Center, West African Science Service Center on Climate Change and Adapted Land Use, Burkina Faso

*Corresponding author, e-mail: kangbenidimobe@yahoo.fr/kangbenidimobe@gmail.com

Received: $12^{\text {th }}$ January 2017 , Accepted: $2^{\text {nd }}$ June 2017

\begin{abstract}
Nazinga Game Ranch (NGR) is a reserve in Burkina Faso involving local communities for securing biodiversity through sustainable management. Yet, its ecosystems are threatened by increasing number of elephants and illegal human activities. Renowned as a model of wildlife participatory management, NGR has mainly been studied for its animal wildlife only. The aim of this study was to uncover ecological effects of recent land management on savanna habitats including tourism, and to conclude on more sustainable options, land use/land cover (LULC) changes and vegetation dynamics in NGR were analyzed. This was accomplished with multi-temporal change detection using Landsat images of 1984, 2002 and 2013 to map seven representative LULC classification categories, and quantitative indices of landscape metrics. The results showed that the LULC dynamics in NGR from 1984 to 2013 was mainly characterized by an expansion of gallery forest, tree savanna and agricultural area and a reduction of shrub savanna, woodland and bare soils. From 2002 to 2013, fragmentation in all land cover types increased at the landscape level, whereas at the class level, it decreased for woodland. Our findings provided evidence of habitat degradation in NGR, due to extensive agriculture, tourism and growing of elephants' population. According to the original management goals and the purposes of the reserve, both fauna and tourism are to be maintained and sustained in a sustainable way. Adaptation of land use and targeted wildlife management are the main requirements for avoiding further degradation of vegetation and thus of the existence basis of local inhabitants, animals and tourism.
\end{abstract}

Keywords: Biodiversity conservation, connectivity, corridors, fragmentation, landscape metrics, patch 
Dimobe K., Goetze D., Ouédraogo A., Forkuor G., Wala K., Porembski S., Thiombiano A.: Spatio-temporal dynamics in land use and habitat fragmentation within a protected area dedicated to tourism in a Sudanian savanna of West Africa

\section{INTRODUCTION}

In Burkina Faso, the conversion of grasslands, woodlands and forests into croplands and pastures has increased dramatically during the past few decades (Reid et al., 2000). The main driving forces of this conversion are human activities that originate from intended land use which directly affect land cover. These driving forces are closely linked to demographic, economic, biophysical, institutional and technological factors (Dimobe et al., 2015; Lambin et al., 2003; Meyer \& Turner, 1994; Ojima et al., 1994). However, there are some protected areas where the vegetation is still preserved, for example the Nazinga Game Ranch (NGR) in Burkina Faso. The NGR was established in 1979 by the Canadian brothers Robert and Clark Lungren who had grown up in the country. After years of observing the devastating impact of cyclical drought on domesticated livestock as well as the effects of poor resource management (deforestation, overgrazing, burning, soil impoverishment, etc.), Clark believed that the key to saving the African continent from famine and its wildlife from extinction could be found in resource development. He set out to prove that when human prosperity can be generated through sustainable management of natural resources, both people and environment do win. Serving as a multi-purpose site, NGR has been dedicated to preserving and promoting wildlife (Portier \& Lungren, 2007). It is an experiment about managing the unique wildlife in West Africa involving local communities and securing biodiversity through sustainable management (Ouédraogo, 2005). It, therefore, has economic importance, providing diversified sources of income for a number of biodiversity conservation actors including local communities (Bouché et al., 2004).

Despite it being a protected ranch, humans and elephants have significantly impacted its vegetation cover (Hema et al., 2011; Hien, 2005; Jachmann \& Croes, 1991). The ranch is now threatened by human activities such as illegal logging and agriculture. There is a strong interaction between flora and fauna, with elephants, other wild animals and humans contributing to current degradation dynamics of vegetation. Though the wildlife participatory management has been renowned as a model, the concomitant development of the vegetation cover of the ranch has never been studied thoroughly. Most of the scientific research focused on the distribution of animal wildlife (Amahowe et al., 2012; Bouché et al., 2004; Hema et al., 2011; Hema et al., 2013; Hien, 2005; Hien et al., 2007; Ouédraogo, 2005; Portier, 2000; Portier \& Lungren, 2007). The only available data on vegetation provides the NGR vegetation map, first conceived by Dekker (1985) and then digitized by Yameogo (1999). In order to evaluate hitherto practiced land use and management in this protected area, it is in a first step essential to detect the changes that have taken place in overall vegetation cover.

In a second step, an analysis of dynamics of selected landscape parameters provides sound information about ecological processes taking place in the area. By studying dynamics of landscape metrics inside and nearby the protected area, management measures can ecologically be evaluated in more detail and be more adequately adapted for more sustainable future management of the NGR, its natural resources, and participation of local communities and stakeholders. In the entire West Africa, very few scientific studies exist on landscape ecology. The ones which are available were carried out in Benin (Mama et al., 2013; Toko et al., 2012) and in Côte d'Ivoire (Barima et al., 2009). So far, no scientific study in this domain that we are aware of has been published referring to Burkina Faso.

The overall aim of this study is to investigate spatial and temporal changes in LULC in NGR in order to draw conclusions on the outcome of hitherto management of wildlife and its utilization, and on the resulting options of higher sustainability in future management of the ranch. Specifically, it aims to (i) detect the spatio-temporal dynamics in vegetation cover 
between 1984 and 2013 on Landsat images and (ii) quantify the degree of LULC change using landscape metrics/fragmentation indices.

\section{MATERIALS AND METHODS}

\section{Study area}

The study was conducted in the Nazinga Game Ranch (NGR) located in southern Burkina Faso, close to the border with Ghana between latitudes $11^{\circ} 01^{\prime}$ and $11^{\circ} 18^{\prime} \mathrm{N}$ and longitudes $1^{\circ} 18^{\prime}$ and $1^{\circ} 43^{\prime} \mathrm{W}$ (Dekker, 1985) (Fig.1). Established in 1979 by the Burkinabe government in collaboration with a Canadian non-profit organization, the African Wildlife Husbandry Development Association, NGR is the first game ranch run in West Africa (Hien, 2005). NGR is not fenced, but is limited by peripheral roads. Despite its status as a protected area, the NGR is being exploited by riparian populations and nomad Peuhl herders. Illegal human activities in the NGR include: farming, poaching, and firewood cutting. Poaching and poor management are once more huge problems NGR is facing due to insufficient number of forest guards. This game ranch was financed by a Canadian cooperation and executed by a Canadian NGO: the Association for the Development and Breeding of the African Fauna (ADEFA). It covers an area of $970 \mathrm{~km}^{2}$ including a core conservation and game viewing zone (9\%), a hunting zone (86\%) and a buffer zone (5\%). The topography is mostly flat with some elevations ranging from 270 to $325 \mathrm{~m}$ altitude. Soils are tropical ferruginous types. Climate is sub-Sudanian (Guinko, 1984). The NGR has a single dry season from October to May and a uni-modal rainy season from June to September each year. The mean annual rainfall is $900 \mathrm{~mm}$ (Hema et al., 2013; Hien et al., 2007). The average monthly temperature ranges between 18.1 and $38.4{ }^{\circ} \mathrm{C}$. The NGR is drained by the Sissili river and its two seasonal confluences, the Dawevele and the Nazinga rivers. From 1979 to1989 eleven dams were built to supply wildlife with permanent water in the dry season. Some dams are used for sport fishing. The vegetation of the ranch is characterized by woody savanna dominated by Combretum spp., Terminalia spp., Vitellaria paradoxa, and Isoberlinia doka.

Wildlife is diverse with nearly 290 species of birds (Portier, 2000), and 11 species of ungulates. Primates encountered are baboon (Papio anubis), vervet (Cercopithecus aethiops), and patas monkey (Erythrocebus patas). The lion (Panthera leo) population went extinct in the 1970s; the only carnivores currently dwelling the game ranch are spotted hyena (Crocuta crocuta), striped hyena (Hyaena hyaena), and the common jackal (Canis aureus).

The NGR is surrounded by 10 villages that it strives to integrate into ranch and tourism management and to provide jobs for local residents. Subsistence farming is the main occupation of the local communities. To each village is assigned a hunting area adjacent to the ranch, which is managed and exploited by village committees to support local development. 
Fig.1: Study area showing (A) the location of Burkina Faso in Africa, (B) the position of NGR with pink colour in Burkina Faso, and $(C)$ the major zones of NGR

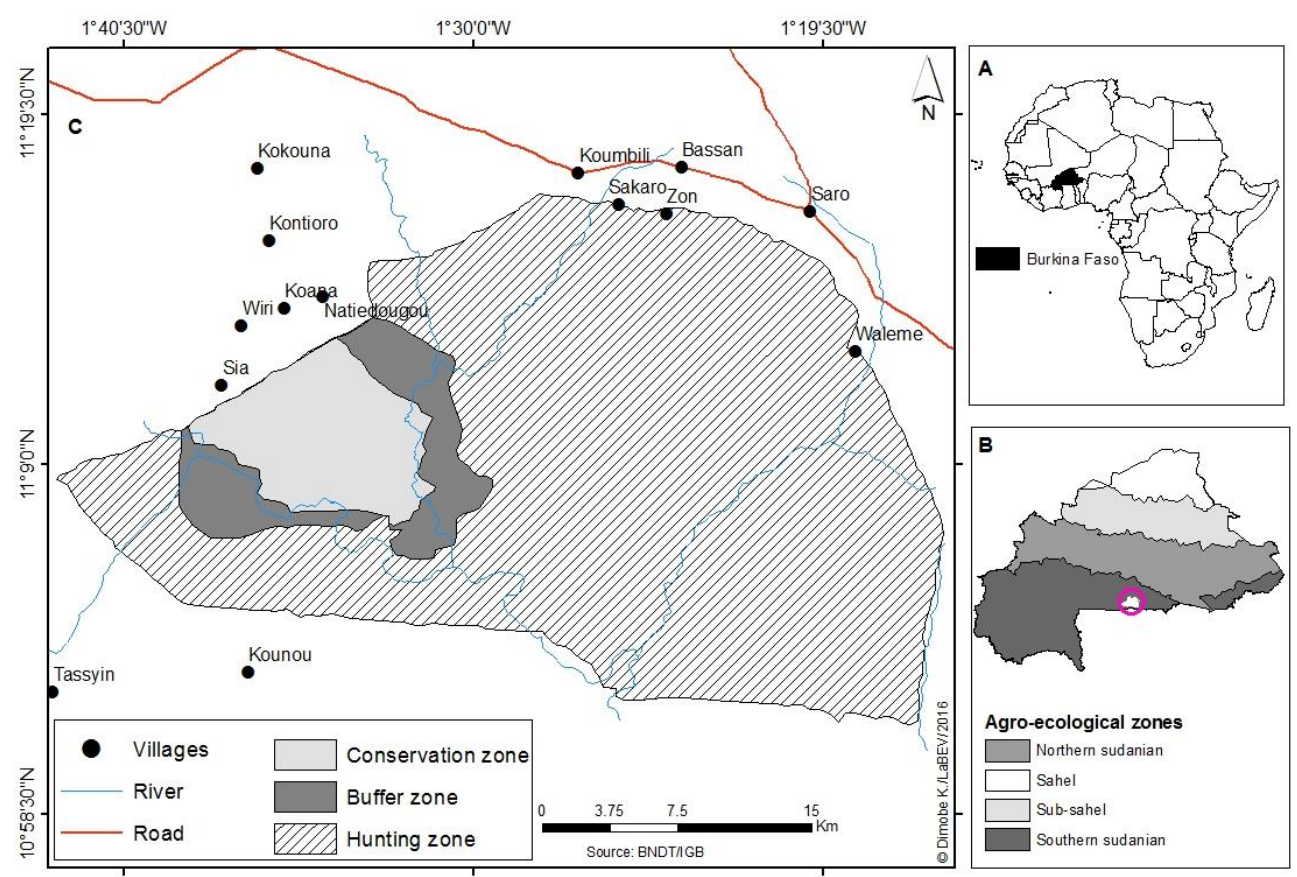

\section{DATA COLLECTION}

\section{Satellite imagery and data pre-processing}

In order to estimate the extent of vegetation cover dynamics, a set of three multi-temporal Landsat images covering path/row 195/52 were downloaded free-of-charge from the United States Geological Survey's (USGS) GLOVIS website (http://glovis.usgs.gov/) for the years 1984, 2002 and 2013. These were: (1) a Landsat TM image acquired in 1984; (2) a Landsat ETM image acquired in 2002 and a Landsat OLI-TIRS image acquired in 2013. Bottomley (1998) and $\mathrm{Lu}$ et al. (2004) underscored the importance of image acquisition dates. Such considerations ultimately improve the accuracy and the potential to discern land cover changes (Lunetta \& Elvidge, 1999) by allowing comparison of images with almost similar vegetation conditions. The acquisition period (November, dry season) was found particularly suitable for separating croplands from grasslands and other types of natural vegetation (Forkuor et al., 2014). All three images were free of clouds. Image-to-image co-registration was performed in order to ensure good alignment of pixels in the respective images.

Fourteen LULC classes were initially defined. Two hundred and fifty field points were taken with a hand-held Global Positioning System (GPS) device in order to train the spectral signature of the LULC classes in a supervised classification scheme. In addition, high-resolution images (QuickBird and Google Earth images) and field data were used to collect LULC reference samples to train and validate the Landsat image classifications. The high-resolution images were acquired as close as possible to the acquisition dates of the Landsat images. One QuickBird image $(2.4 \mathrm{~m} \times 2.4 \mathrm{~m})$ was acquired from 12 November 
2012. In addition, Google Earth images (2.4 m × $2.4 \mathrm{~m}$ ) from October 2012, November 2012, December 2012 and December 2013 were used.

LULC areas that had remained stable since 2013 were sampled based on local population knowledge (Zoungrana et al., 2015). Additionally, five digital photographs were taken of different LULC classes (i.e. one each towards north, south, east, west and one from the north position to the middle of the field) in order to complement the surveys and provide visual documentation of these classes. In order to match Landsat pixels, homogeneous areas of $30 \times 30 \mathrm{~m}^{2}$ were surveyed for each LULC as recommended by Lewis (1998), and the coordinates of the center recorded. Training areas for the spectral signatures of older images were selected in those sites where LULC had remained unchanged or by using areas with similar spectral characteristics.

The spatial data used in this study were geometrically adjusted (co-registration) to the Landsat images and geo-referenced to UTM WGS84 zone 30 north.

\section{Landscape metrics}

Landscape metrics act as quantitative link between landscape patterns and ecological or environmental processes.

They display numerical information about landscape composition, configuration and dimension, and allow for comparisons of different times and even help to recreate future scenarios (del Castillo et al., 2015; Vila Subirós et al., 2006). Consequently, landscape metrics are widely used in the literature to study large natural areas, forest dynamics, natural parks or urban expansion among others (Baskent \& Kadiogullari, 2007; Pôças et al., 2011; Terzioğlu et al., 2009). These metrics can be derived for one of three levels: patch level (defined for individual patches), class level (characteristics of all patches in a given class), and landscape level (integrated over all patch types or classes over the extent of the data). In this study landscape and class level metrics were used as patch level metrics are not useful for our purposes. Class metrics represent the spatial distribution and pattern within a landscape of a single patch type; whereas landscape metrics represent the spatial pattern of the entire landscape mosaic, considering all patch types simultaneously (McGarigal et al., 2002). Patch metrics are excessively disaggregated and can be particularly useful when analyzing single patches for specific purposes (e.g., habitat studies, reserves delineation, edge effects) (Cunningham, 2000). Complete descriptions of these metrics and equations for their calculation are provided in McGarigal et al. (2012).

\section{DATA ANALYSIS}

\section{Image classification}

Supervised classification was performed, using the maximum likelihood algorithm (MLC) on each image, to generate LULC maps for 1984, 2002 and 2013. Seven LULC classes - gallery forest, woodland, tree savanna, shrub savanna, farm/fallow, bare soil, and water body - representing the dominant LULC categories were finally identified in the study area.

As a prerequisite to supervised classification, training sites were developed for all the LULC classes mentioned above for each image. Field data enabled the generation of training and validation data for the classification which was performed using ENVI 4.7 software. Polygons of homogeneous pixels were drawn around each truth point for each LULC class and saved as vector layer of training areas. Landsat pixels that overlap the training areas were then used to perform the classification. Two sets of training data that had been collected from 
the field surveys were developed - one for classification (two-thirds) and one (the remaining third) for validation.

\section{Accuracy assessment}

A classification is not complete unless its accuracy is assessed (Lillesand et al., 2004). Thus, the classified images were validated using one-third of field data. Points were selected randomly and, at each point, the classified image pixel was compared with the reference data of LULC class. Overall accuracy for the 2013 LULC map was assessed using ground reference points collected in the field, using a hand-held GPS (Congalton \& Green, 2008). Fifty percent of pixels in these validation sites were generated randomly and used to generate a classification error matrix for each classified image. Afterwards, overall accuracy, user's and producer's accuracies and the kappa statistic were then derived from the error matrices.

\section{Landscape metrics}

In order to calculate landscape metrics, LULC maps were converted into Grid format using ERDAS Imagine 2013 and introduced into the FRAGSTATS 4.2 software. The following metrics were quantified:

\section{- $\quad$ Class level metrics}

To assess landscape composition we calculated:

(a) Number of patches $(N P)$ which is the number of patches of the corresponding patch type (class). Higher $N P$ indicates greater fragmentation.

$$
N P=n i
$$

Where $n i=$ number of patches in the landscape of patch type (class) $i$.

(b) Patch density $(P D)$ : is the number of patches of the corresponding patch type divided by total landscape area $\left(\mathrm{m}^{2}\right)$.

$$
P D=\frac{n i}{A}(10000) *(100)
$$

Where $n i=$ number of patches in the landscape of patch type (class) $i$, $A=$ total landscape area $\left(\mathrm{m}^{2}\right)$.

(c) Largest Patch Index (LPI): the area of the largest patch in each class (in hectares).

$$
L P I=\frac{\max (a i j)}{A} *(100)
$$

Where $a i j=$ area $\left(\mathrm{m}^{2}\right)$ of patch $i j$.

$A=$ total landscape area $\left(\mathrm{m}^{2}\right)$.

(d) Class percentage of landscape (PLAND). It equals the percentage of the landscape comprised of the corresponding class type

$$
P L A N D=P i=\frac{\sum_{j=1}^{n} a_{i j}}{A} * 100
$$

$P i=$ proportion of the landscape occupied by patch type (class) $i$; $a i j=$ area $\left(\mathrm{m}^{2}\right)$ of patch $i j ; A$ $=$ total landscape area $\left(\mathrm{m}^{2}\right)$. 
(e) Patch cohesion index (COHESION) equals 1 minus the sum of patch perimeter (in terms of number of cell surfaces) divided by the sum of patch perimeter times the square root of patch area (in terms of number of cells) for patches of the corresponding patch type, divided by 1 minus 1 over the square root of the total number of cells in the landscape, multiplied by 100 to convert to a percentage.

$$
\text { COHESION }=\left[1-\frac{\sum_{j=1}^{m} P i j}{\sum_{j=1}^{m} P i j \sqrt{a i j}}\right]\left[1-\frac{1}{\sqrt{A}}\right] *(100)
$$

Where $P i j=$ perimeter of patch $i j$ in terms of number of cell surfaces.

aij $=$ area of patch $\mathrm{ij}$ in terms of number of cells.

$A=$ total number of cells in the landscape.

(f) Class total Area (CA) occupied by the class $j$ (in ha) was calculated according to the equation below where aij was the area of the $i$-th patch in the class $\mathrm{j}$ :

$$
C A=\sum_{j=1}^{n} a_{i j}\left(\frac{1}{10000}\right)
$$

(g) Mean Euclidean nearest neighbor distance (ENN_MN),

$$
E N N_{-} M N=\frac{\sum_{j=1}^{n} h_{i j}}{n_{i}}
$$

Where $h i j=\operatorname{distance}(\mathrm{m})$ from patch $i j$ to nearest neighboring patch of the same type (class), based on patch edge-to-edge distance, computed from cell center to cell center.

\section{- $\quad$ Landscape level metrics}

For the analysis of landscape configuration, we calculated:

(a) Number of patches $(N P)$ which is the number of patches of the corresponding patch type (class). Higher NP indicates greater fragmentation.

$$
N P=n i
$$

Where $\mathrm{ni}=$ number of patches in the landscape of patch type (class) $i$.

(b) Patch density $(P D)$ : equals the number of patches of the corresponding patch type divided by total landscape area $\left(\mathrm{m}^{2}\right)$.

$$
P D=\frac{n i}{A}(10000)(100)
$$

Where $n i=$ number of patches in the landscape of patch type (class) $i, A=$ total landscape area $\left(\mathrm{m}^{2}\right)$.

(c) Largest Patch Index ( $L P I)$ : the area of the largest patch in each class (in hectares).

$$
L P I=\frac{\max (a i j)}{A}(100)
$$

Where $a i j=$ area $\left(\mathrm{m}^{2}\right)$ of patch $i j, A=$ total landscape area $\left(\mathrm{m}^{2}\right)$.

(d) Shannon's Diversity index (SHDI): equals minus the sum, across all patch types, of the proportional abundance of each patch type multiplied by that proportion

$$
S H D I=-\sum_{i=1}^{m}\left(P_{i} \ln P_{i}\right)
$$


Dimobe K., Goetze D., Ouédraogo A., Forkuor G., Wala K., Porembski S., Thiombiano A.: Spatio-temporal dynamics in land use and habitat fragmentation within a protected area dedicated to tourism in a Sudanian savanna of West Africa

Where $P i=$ proportion of the landscape occupied by patch type (class) $i$.

(e) Landscape total area (TA) occupied by the class $j$ (in ha) was calculated according to the equation below where $A$ was the area of the $i$-th patch in the class $j$ :

$$
T A=\sum_{i=1}^{n} A_{i j}
$$

(f) The mean patch area (AREA_MN) (the average value of the patches' area of the class j) was calculated according to the following formula:

$$
\text { AREA_MN }=\frac{C A}{n_{j}}
$$

Overall, ten landscape metrics were calculated using FRAGSTATS software algorithms (McGarigal et al., 2002) (Table 4). Landscape metrics selection was made based on criteria provided in the literature (Baskent \& Kadiogullari, 2007; Bracchetti et al., 2012; Teixido et al., 2010). FRAGSTATS was used because it provides a detailed suite of spatial statistics and descriptive metrics of pattern at the patch, class, and landscape levels (Nagendra et al., 2004). While FRAGSTATS provides a large number of spatial metrics, a specific subset of them was specifically selected for this study (Table 1).

Table 1: Summary table of studied landscape metrics

\begin{tabular}{llll}
\hline Index & Acronym & Analysis level & Landscape structure concept \\
\hline Total landscape area (ha) & TA & Landscape & Fragmentation \\
Percentage of landscape & PLAND & Class & Fragmentation \\
Class area & CA & Class & Fragmentation \\
Number of patches & NP & Landscape / Class & Fragmentation \\
Patch density (\#/100 ha) & PD & Landscape / Class & Fragmentation \\
Largest patch index & LPI & Landscape / Class & Fragmentation \\
Patch area (mean) & AREA_MN & Landscape / Class & Fragmentation \\
$\begin{array}{l}\text { Euclidean nearest neighbor distance } \\
\text { (mean) }\end{array}$ & ENN_MN & Class & Connectivity \\
$\begin{array}{l}\text { Patch cohesion index } \\
\text { Shannon's diversity index }\end{array}$ & COHESION & Class & Connectivity \\
& SHDI & Landscape & Heterogeneity \\
\hline
\end{tabular}




\section{RESULTS}

\section{Vegetation types in the NGR}

Based on data collected in the field and according to the agreement of Yangambi concerning nomenclature of African vegetation types (Aubreville, 1957), vegetation types encountered in the study area were defined and described (Table 2). The vegetation that dominates the ranch is woody savanna (see Table 2 ).

\section{Table 2: Description of LULC classes identified in the NGR}

\begin{tabular}{|c|c|}
\hline LULC type & Description \\
\hline Gallery forest (1.47\%) & $\begin{array}{l}\text { Vegetation with native tree species which form a corridor along rivers with } \\
\text { species such as Mitragyna inermis, Cola laurifolia }\end{array}$ \\
\hline Woodland $(9.45 \%)$ & $\begin{array}{l}\text { Vegetation with native tree species } \geq 7 \mathrm{~m} \text { tall, 20-70 \% tree cover, with species } \\
\text { such as Anogeissus leiocarpa, Diospyros mespiliformis, Isoberlinia doka, } \\
\text { Burkea africana, Vitellaria paradoxa, Afzelia africana, Lannea acida, } \\
\text { Pterocarjpus erinaceus, Combretum nigricans }\end{array}$ \\
\hline Tree savanna (35.98 \%) & $\begin{array}{l}\text { Vegetation with native tree species } \geq 7 \mathrm{~m} \text { tall, } 2-20 \% \text { tree cover, with species } \\
\text { such as Vitellaria paradoxa, Detarium microcarpum, Isoberlinia doka, } \\
\text { Crossopteryx febrifuga, Terminalia laxiflora }\end{array}$ \\
\hline Shrub savanna $(51.86 \%)$ & $\begin{array}{l}\text { Vegetation with native shrub species }<7 \mathrm{~m} \text { tall, shrub cover } 2-70 \% \text {, with } \\
\text { species such as Terminalia laxiflora, Piliostigma thonningii, Maytenus } \\
\text { senegalensis, Combretum fragrans }\end{array}$ \\
\hline
\end{tabular}

The values in brackets represent the percentage of each land cover in the NGR

\section{Land use and land cover dynamics}

The results of classification reveal good agreement with the real world as indicated by overall classification accuracies and Kappa statistics for 1984, 2002 and 2013 (Table 3). The user's accuracy for woodlands and farm/fallow on one hand and that of bare soil on other hand were particularly low for 1984 and 2013 respectively. Overall, the accuracy of the classification maps increased from 1984 to 2013, apart from the user's accuracy values for tree savannas that were higher in 2002. Classification maps were produced for each acquisition date (Fig. 2) and the individual class area and change statistics for the three study dates are summarized in Table 4.

Table 3: Classification accuracy for 1984, 2002 and 2013 images

\begin{tabular}{lllllll}
\hline \multirow{2}{*}{ LULC types } & $\mathbf{1 9 8 4}$ & \multicolumn{3}{c}{$\mathbf{2 0 0 2}$} & $\mathbf{2 0 1 3}$ & \\
\cline { 2 - 7 } & PA $\mathbf{\%})$ & UA (\%) & PA (\%) & UA (\%) & PA (\%) & UA (\%) \\
\hline Gallery forest & 58.47 & 89.91 & 93.52 & 98.19 & 94.67 & 99.28 \\
Woodland & 88.55 & 16.35 & 91.06 & 63.24 & 84.94 & 73.21 \\
Tree savanna & 78.40 & 98.89 & 94.66 & 99.74 & 76.47 & 20.80 \\
Shrub savanna & 94.46 & 83.57 & 98.70 & 78.35 & 89.74 & 62.50 \\
Farm/fallow & 97.83 & 7.35 & 95.01 & 86.90 & 95.47 & 99.99 \\
Bare soil & 92.73 & 50.50 & 96.97 & 60.38 & 98.75 & 13.86 \\
Water body & 100 & 10.59 & 100 & 100 & 97.64 & 99.79 \\
Overall accuracy & 77.23 & & 94.37 & & 94.88 & \\
Kappa & 0.60 & & 0.92 & & 0.90 & \\
\hline
\end{tabular}

PA: Producer's accuracy, UA: User's accuracy 
Fig. 2: Land use and land cover maps of the Nazinga Game Ranch in 1984, 2002 and 2013
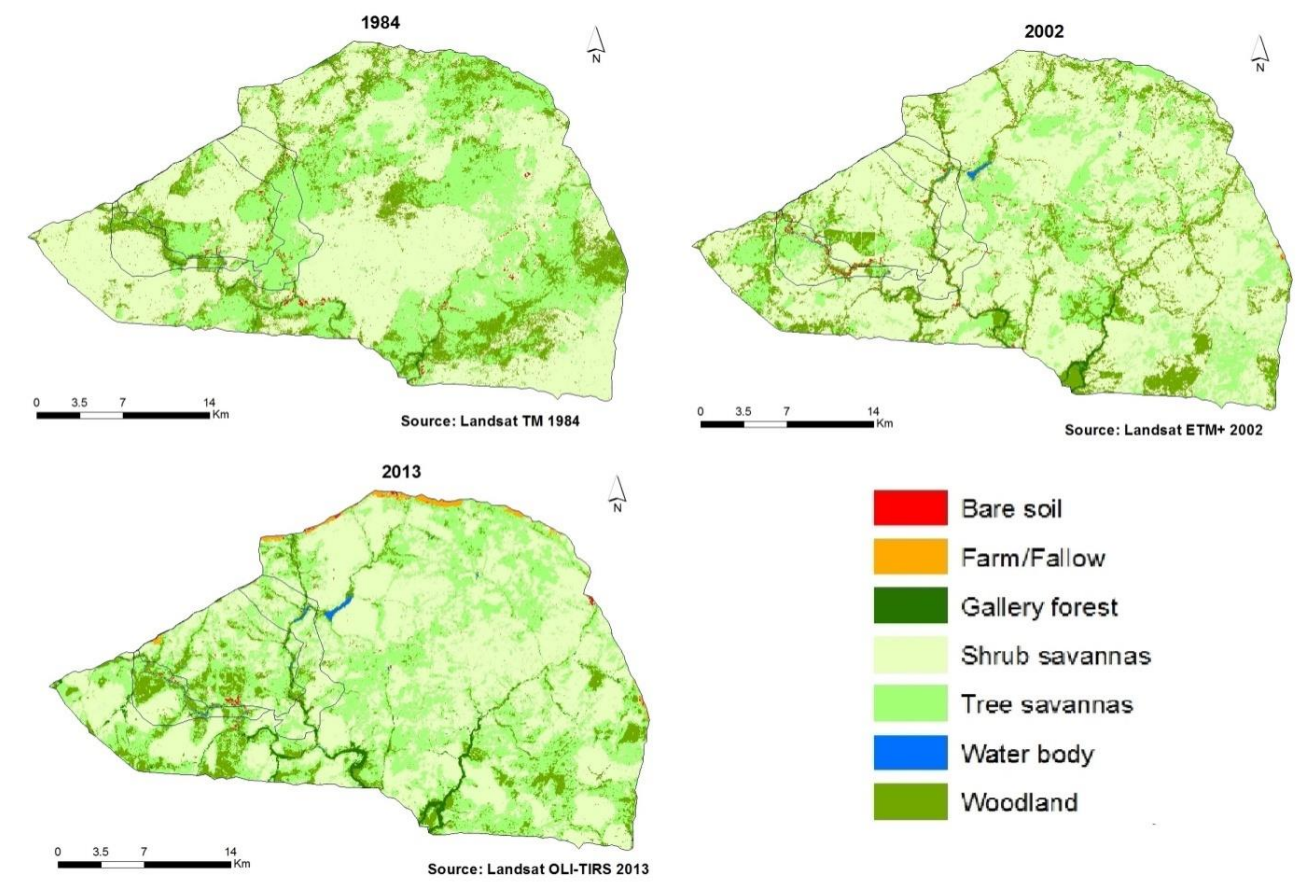

Table 4: Summary of Landsat classification area statistics for 1984, 2002 and 2013

\begin{tabular}{|c|c|c|c|c|c|c|c|}
\hline \multirow[b]{2}{*}{ Land cover class } & \multicolumn{2}{|l|}{1984} & \multicolumn{2}{|l|}{2002} & \multicolumn{2}{|l|}{2013} & \multirow{2}{*}{$\begin{array}{l}\text { Relative change, } \\
1984-2013(\%)\end{array}$} \\
\hline & Area (ha) & $\%$ & Area (ha) & $\%$ & Area (ha) & $\%$ & \\
\hline Bare soil & 356.49 & 0.40 & 283.95 & 0.32 & 207.90 & 0.24 & -41.68 \\
\hline Farm/fallow & 8.73 & 0.01 & 35.37 & 0.04 & 682.92 & 0.78 & 7722.68 \\
\hline Gallery forest & 713.61 & 0.81 & 620.64 & 0.70 & 1283.13 & 1.47 & 79.81 \\
\hline Shrub savanna & 46523.28 & 52.58 & 59116.54 & 66.81 & 45366.61 & 51.86 & -2.49 \\
\hline Tree savanna & 27801.27 & 31.42 & 15960.87 & 18.04 & 31471.20 & 35.98 & 13.20 \\
\hline Water body & 21.24 & 0.02 & 111.96 & 0.13 & 199.26 & 0.23 & 838.14 \\
\hline Woodland & 13055.31 & 14.76 & 12350.61 & 13.96 & 8268.84 & 9.45 & -36.66 \\
\hline
\end{tabular}

Shrub savanna consistently represented the most widespread land cover type in the study area. In 1984, this land cover type constituted about $52.58 \%$ of the total area of NGR. In 2002 and 2013, it accounted for $66.81 \%$ and $51.86 \%$, respectively (Table 4). This reveals loss of shrub savanna between 2002 and 2013, contrary to the period between 1984 and 2002 . 
The loss of shrub savanna was due to conversion of 7516.26 ha into tree savanna (Table 5). The net loss of shrub savanna over the entire analysis period was 1156.67 ha $(2.49 \%)$.

In 1984, about $31.42 \%$ of NGR area was covered by tree savanna, that, in 18 years later had declined to $18.04 \%$ and subsequently increased to $35.98 \%$ in 2013 (Table 4). The decrease of tree savanna was attributed to its conversion to other LULC. About 8362.44 ha of tree savanna was converted into shrub savanna and 2605.5 ha into woodland, respectively. Finally, a total net gain of 3669.93 ha of tree savanna was recorded in the NGR over the nearly three decades considered.

A continuous decrease of woodland cover was observed over the study period. Of the total area of the NGR in 1984, woodland constituted about $14.76 \%$. In 2002 and 2013, it accounted for $13.96 \%$ and $9.45 \%$, respectively, of the total study area (Table 4). The net loss of woodland cover was 4786.47 ha $(36.66 \%)$, mainly due to conversion into shrub savanna and tree savanna (Table 5). Besides human impact, woodlands are typically destroyed by elephants in the ranch (Fig. 3).

Fig. 3: Trees damaged by elephants
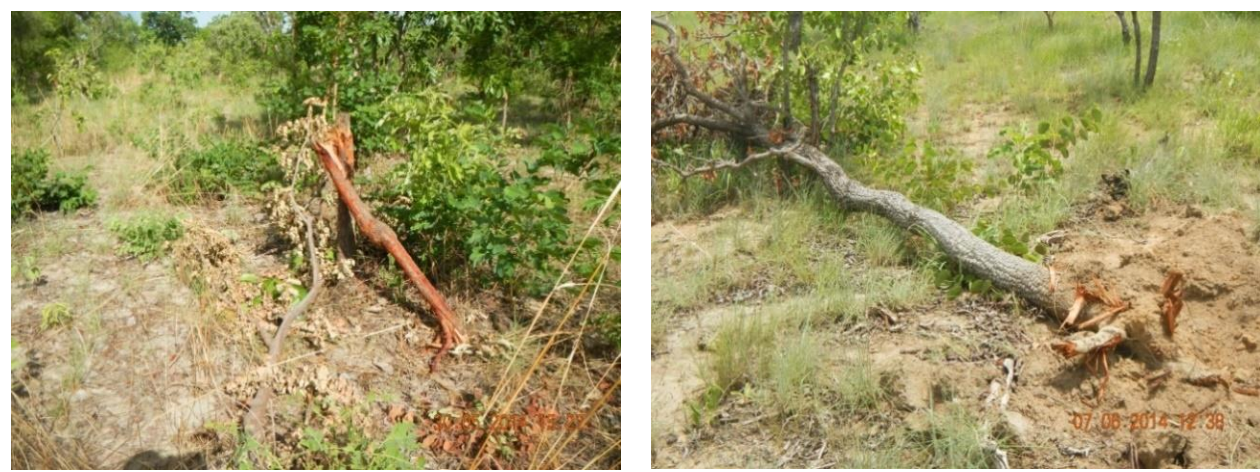

The gallery forest area exhibited a small decrease between 1984 and $2002(0.81 \%$ to $0.7 \%$ ) and subsequently, it sharply increased to $1.47 \%$ of the total area of NGR. From 1984 to 2002 , the rate of gallery forest decline was about 5.165 ha per annum whereas its rate of expansion from 2002 to 2013 was about 60.23 ha per year. During the whole study period, there was a net gain of 569.52 ha $(79.81 \%)$.

Of the total land surface in the NGR, the proportions of agricultural land in 1984, 2002 and 2013 were $0.01 \%, 0.04 \%$ and $0.78 \%$, respectively (Table 4). This showed a continuous expansion of agricultural land. Between 1984 and 2002, agricultural areas increased by $305.15 \%$ which is a rate of 1.48 ha per year. This rate was 58.87 ha per year between 2002 and 2013 , and 23.25 ha per year over the 29 years. The observed increase in agricultural land from 1984 to 2002 was due to the transformation of 21.69 ha of woodland, 7.47 ha of tree savanna and 5.13 ha of shrub savanna into agricultural land. During the second period (2002-2013), 441.9 ha of shrub savanna, 127.17 ha of tree savanna and 97.11 ha of woodland were converted into agricultural land (Table 5).

A small but consistent increase was observed in water bodies due to construction of dams in the study area. In total eleven dams were built to supply wildlife with permanent water in the dry season. Some reservoirs are used for sports fishing. 
Dimobe K., Goetze D., Ouédraogo A., Forkuor G., Wala K., Porembski S., Thiombiano A.: Spatio-temporal dynamics in land use and habitat fragmentation within a protected area dedicated to tourism in a Sudanian savanna of West Africa

Table 5: Change area matrices of land cover classes in 1984, 2002 and 2013 (area in ha)

\begin{tabular}{|c|c|c|c|c|c|c|c|c|}
\hline \multirow[b]{2}{*}{$\begin{array}{l}\text { Land cover } \\
\text { class in } 1984\end{array}$} & \multicolumn{8}{|c|}{ Land cover class in 2002} \\
\hline & GF & $\mathrm{W}$ & $\mathrm{TS}$ & Ss & $\mathrm{FF}$ & Bs & $\mathrm{Wb}$ & $\begin{array}{l}\text { Total } \\
(1984)\end{array}$ \\
\hline GF & 184.86 & 213.12 & 72.99 & 228.24 & 0.18 & 8.55 & 5.67 & 713.61 \\
\hline W & 355.5 & 3607.29 & 2605.5 & 6366.42 & 21.69 & 51.57 & 47.34 & 13055.31 \\
\hline TS & 50.85 & 3315.6 & 4871.97 & 19441.89 & 7.47 & 75.6 & 37.89 & 27801.27 \\
\hline Ss & 28.08 & 5184.54 & 8362.44 & 32849.28 & 5.13 & 80.28 & 13.5 & 46523.25 \\
\hline $\mathrm{FF}$ & 0 & 0.54 & 1.08 & 6.66 & 0 & 0.45 & 0 & 8.73 \\
\hline Bs & 1.35 & 28.71 & 45.9 & 211.59 & 0.9 & 65.43 & 2.61 & 356.49 \\
\hline $\mathrm{Wb}$ & 0 & 0.81 & 0.99 & 12.42 & 0 & 2.07 & 4.95 & 21.24 \\
\hline \multirow[t]{2}{*}{ Total (2002) } & 620.64 & 12350.61 & 15960.87 & 59116.5 & 35.37 & 283.95 & 111.96 & \\
\hline & \multicolumn{8}{|c|}{ Land cover class in 2013} \\
\hline $\begin{array}{l}\text { Land cover } \\
\text { class in } 2002\end{array}$ & GF & $\mathrm{W}$ & TS & Ss & $\mathrm{FF}$ & Bs & $\mathrm{Wb}$ & $\begin{array}{l}\text { Total } \\
(2002)\end{array}$ \\
\hline GF & 558.45 & 50.85 & 8.55 & 1.62 & 0.18 & 0.18 & 0.81 & 620.64 \\
\hline $\mathrm{W}$ & 653.94 & 3322.89 & 5406.21 & 2816.82 & 97.11 & 4.86 & 48.78 & 12350.61 \\
\hline TS & 37.17 & 1710.9 & 6556.68 & 7516.26 & 127.17 & 10.71 & 1.98 & 15960.87 \\
\hline Ss & 33.21 & 3156.75 & 19391.13 & 35939.79 & 441.9 & 122.76 & 30.96 & 59116.5 \\
\hline FF & 0 & 2.25 & 12.33 & 6.39 & 12.06 & 2.34 & 0 & 35.37 \\
\hline Bs & 0.18 & 23.85 & 90.63 & 80.28 & 4.5 & 67.05 & 17.46 & 283.95 \\
\hline $\mathrm{Wb}$ & 0.18 & 1.35 & 5.67 & 5.49 & 0 & 0 & 99.27 & 111.96 \\
\hline \multirow[t]{2}{*}{ Total (2013) } & 1283.13 & 8268.84 & 31471.2 & 46366.65 & 682.92 & 207.9 & 199.26 & \\
\hline & \multicolumn{8}{|c|}{ Land cover class in 2013} \\
\hline $\begin{array}{l}\text { Land cover } \\
\text { class in } 1984\end{array}$ & GF & $\mathrm{W}$ & $\mathrm{TS}$ & Ss & $\mathrm{FF}$ & Bs & $\mathrm{Wb}$ & $\begin{array}{c}\text { Total } \\
(1984) \\
\end{array}$ \\
\hline GF & 220.86 & 137.88 & 168.21 & 163.53 & 9.99 & 0.36 & 12.78 & 713.61 \\
\hline W & 650.34 & 2512.89 & 5343.84 & 4258.44 & 191.52 & 19.71 & 78.57 & 13055.31 \\
\hline TS & 226.44 & 2229.39 & 9772.83 & 15267.78 & 181.8 & 54.45 & 68.58 & 27801.27 \\
\hline Ss & 181.62 & 3348 & 16046.91 & 26531.64 & 298.26 & 89.01 & 27.81 & 46523.25 \\
\hline FF & 0 & 0.45 & 2.97 & 5.04 & 0.09 & 0.18 & 0 & 8.73 \\
\hline Bs & 3.87 & 39.06 & 131.04 & 135.36 & 0.99 & 42.21 & 3.96 & 356.49 \\
\hline $\mathrm{Wb}$ & 0 & 1.17 & 5.4 & 4.86 & 0.27 & 1.98 & 7.56 & 21.24 \\
\hline Total (2013) & 1283.13 & 8268.84 & 31471.2 & 46366.65 & 682.92 & 207.9 & 199.26 & \\
\hline
\end{tabular}

GF: Gallery forest, W: Woodland, TS: Tree savanna, Ss: Shrub savanna, FF: Farm/fallow, Bs: Bare soil, Wb: Water body 


\section{Landscape metrics}

Tables 6 and 7 present metrics calculated using FRAGSTATS 4.2 at both the landscape and class levels.

At class level, between 1984 and 2002, the fragmentation indices (NP, PD, LPI and AREA_MN) of vegetation classes decreased while the connectivity indices (ENN_MN, COHESION) increased in general except for woodland and shrub savanna. Only farming areas experienced an increase in the fragmentation indices due to extension (Table 6). During this period, we observed that the percentage of landscape (PLAND) comprised of large vegetation fragments decreased for gallery forest (from 0.504 to $0.318 \%$ ), woodland (from 9.214 to $6.327 \%$ ), tree savanna (19.621 to 8.177) and shrub savanna (32.835 to 30.285 ). The observed decrease in the fragmentation indices especially NP during 1984-2002 corresponds to simplification of the landscape structure. Woodlands had the smallest reduction in patch number from 10219 to 8408 (17.72\%, or 100.61 patches per year).

From 2002 to 2013, the fragmentation gain was present in all vegetation types except for woodland where there was a noticeable decrease in fragmentation.

The analysis of changes in the spatial structure of the NGR's landscape between 1984 and 2013 revealed that tree savannas are plant communities which had become the most fragmented during the 29-year period (Table 6). This fragmentation pattern is confirmed by the increase of NP (from 7474 to 7606), PD (from 5.275 to 5.3681) and decrease of LPI (from 6.688 to 3.7756$)$.

The Euclidean Nearest Neighbour Distance (ENN_MN) and Patch Cohesion Index (COHESION) reflect a high decrease in class connectivity. Among the land cover classes, the most obvious change is increased aggregation of shrub savannas.

In 1984, various vegetation cover classes were often interspersed with still single patches of agricultural land having a total area of only 8.73 ha (Table 5). By 2013 the patches of agricultural land had often coalesced (decrease of ENN_MN and increase of COHESION) through conversion of near natural vegetation, increasing their total area (CA) by more than 70 times to 682.920 ha (Table 6).

Concerning fragmentation at the landscape level, the same trends of simplification between 1984 and 2002 and fragmentation between 2002 and 2013 were apparent (Table 7). From 1984 to 2002, the number of patches (NP) in the study area decreased (from 27875 to 17834), and the mean patch area (AREA_MN) increased (from 5.083 to 10.945), showing a trend towards an increasingly large-grained landscape. From 2002 to 2013, NP increased and AREA_MN decreased showing a fragmentation process in the NGR.

Shannon's Diversity index (SHDI), which explains fragmentation, decreased by $16.03 \%$ (from 1.316 to 1.105 ) between 1984 and 2002, and increased by $19.37 \%$ (from 1.105 to 1.319) between 2002 and 2013. Hence, the landscape was dominated by heterogeneous land use types in 2013, against in 1984 by more homogenous distribution of land use types. This reveals that the area, as of the year 2013, was more fragmented than it had been when the ranch was created in 1979.

Between 1984 and 2002, Largest Patch Index (LPI) increased by $79.57 \%$ (30.445 to 54.672). This clearly shows that some land use classes dominated the landscape throughout these periods. However, from 2002 to 2013, LPI decreased, indicating that landscape fragmentation increased during this period (Table 7). 
Dimobe K., Goetze D., Ouédraogo A., Forkuor G., Wala K., Porembski S., Thiombiano A.: Spatio-temporal dynamics in land use and habitat fragmentation within a protected area dedicated to tourism in a Sudanian savanna of West Africa

Table 6: Landscape metrics at the class level for 1984, 2002 and 2013

\begin{tabular}{lllllllll}
\hline TYPE & CA & PLAND & NP & PD & LPI & AREA_MN & ENN_MN & COHESION \\
\hline $\mathbf{1 9 8 4}$ & & & & & & & & \\
Gallery forest & 713.610 & 0.504 & 3154 & 2.226 & 0.027 & 0.226 & 194.017 & 63.301 \\
Woodland & 13055.310 & 9.214 & 10219 & 7.212 & 1.005 & 1.278 & 89.155 & 97.345 \\
Tree savanna & 27801.270 & 19.621 & 7474 & 5.275 & 6.688 & 3.720 & 98.649 & 99.386 \\
Shrub savanna & 46523.250 & 32.835 & 5845 & 4.125 & 10.411 & 7.960 & 86.270 & 99.548 \\
Farm/fallow & 8.730 & 0.006 & 51 & 0.036 & 0.001 & 0.171 & 1155.554 & 42.542 \\
$\mathbf{2 0 0 2}$ & & & & & & & & \\
Gallery forest & 620.640 & 0.318 & 538 & 0.276 & 0.088 & 1.154 & 244.680 & 93.075 \\
Woodland & 12350.610 & 6.327 & 8408 & 4.307 & 0.365 & 1.469 & 92.963 & 95.673 \\
Tree savanna & 15960.870 & 8.177 & 5657 & 2.898 & 0.511 & 2.821 & 98.428 & 97.128 \\
Shrub savanna & 59116.500 & 30.285 & 2580 & 1.322 & 24.759 & 22.913 & 79.567 & 99.891 \\
Farm/fallow & 35.370 & 0.018 & 74 & 0.038 & 0.007 & 0.478 & 709.762 & 81.557 \\
$\mathbf{2 0 1 3}$ & & & & & & & & 94.57 \\
Gallery forest & 1283.130 & 0.906 & 911 & 0.643 & 0.258 & 1.409 & 148.484 & 94.545 \\
Woodland & 8268.840 & 5.836 & 5284 & 3.729 & 0.347 & 1.565 & 105.524 & 94.402 \\
Tree savanna & 31471.200 & 22.212 & 7606 & 5.368 & 3.776 & 4.138 & 79.666 & 99.146 \\
Shrub savanna & 46366.650 & 32.724 & 4252 & 3.001 & 18.029 & 10.905 & 81.841 & 99.719 \\
Farm/fallow & 682.920 & 0.482 & 162 & 0.114 & 0.128 & 4.216 & 337.776 & 95.370 \\
\hline & & & & & & & & \\
\end{tabular}

Table 7: Landscape metrics at landscape level

\begin{tabular}{lllllll}
\hline LID & TA & NP & PD & LPI & AREA_MN & SHDI \\
\hline 1984 & 141688.3 & 27875 & 19.6735 & 30.445 & 5.083 & 1.316 \\
2002 & 141688.3 & 17834 & 9.1364 & 54.672 & 10.945 & 1.105 \\
2013 & 141688.3 & 18691 & 13.1916 & 30.445 & 7.581 & 1.319 \\
\hline
\end{tabular}

\section{Discussion}

The classification technique used to derive the LULC maps for 1984, 2002 and 2013 was the traditional MLC. The MLC is based on the probability that a pixel belongs to a particular class. The advantage of MLC is that it is less time consuming (Alqurashi \& Kumar, 2014). The overall LULC classification accuracy levels for the three dates were sufficient for investigating the study area because they satisfy the minimum accuracy stipulated by Anderson (1976) for satellite-derived LULC maps.

The decline of shrub savanna and woodland observed in this study suggests disturbance effects on vegetation. They should mostly be linked to illegal wood cutting, bushfire, illegal 
farming and impact of elephants (Loxodonta africana) on some woody species, and consequently reduce woody species richness. Loss and fragmentation of woody vegetation are key conservation issues in our study area as elsewhere. According to Hien (2005) NGR has been encroached by elephants for many years. Altogether, the NGR and Sissili and Kaboré Tambi National Park hosted 603 elephants, and this elephant population is increasing (Bouché et al., 2003). This concentration of elephants has an obviously negative effect on vegetation structure and composition as elephants debark, browse intensively and destroy trees. Many studies have reported that elephants can precipitate declines in tree populations or marked changes in community composition (Guldemond \& Van Aarde, 2007; Landman et al., 2008; Nasseri et al., 2011; Swanepoel \& Swanepoel, 1986). Satellite images used in this study had been recorded in the dry season. Thus, the degradation of vegetation by elephants in the buffer and conservation zones of NGR can be explained by the fact that during the dry season which corresponds to the hunting period of tourists, elephants may have moved to the more secure and less disturbed areas like the core of NGR, where sufficient water resources are available (Bouché et al., 2004; Hien et al., 2007). According to Hema et al. (2011) who worked on the distribution of elephants within NGR - proximity of water is one of the factors determining elephant presence in a location during the dry season.

Increasing demand for agricultural land and cutting of shrubs and trees for fuel wood were the main causes for the observed dynamics of shrub savanna and woodland in the NGR. The increase in agricultural land for subsistence farming in the NGR between 1984 and 2013 can also be linked to an increase in poverty and population density. This finding conforms to previous studies by Chambers (1986) and Dimobe et al. (2015) who found that basic needs and poverty are interwoven key factors that lead to overexploitation of biological resources and to habitat degradation in protected areas. For there may not be alternatives to meeting the communities' basic needs outside the protected areas, and even if these alternatives do exist, the level of poverty may hinder the procurement of these needs, and local people would have to fall back on satisfying their needs from these protected areas. Population increase leading to settlement expansion has encouraged people to penetrate protected areas and destroy habitats with high biodiversity (Ikpa et al., 2009).

Expansion of agricultural land and concomitant vegetation degradation for creating room for mechanized farming and tourism businesses are serious problems in NGR. Increasing frequency of tourist arrivals has led to an increasing number of tourist vehicles in the ranch. According to Hien et al. (2007) about 5000 visitors each year enter NGR from the registration post on the eastern side of the ranch and drive $35 \mathrm{~km}$ on the main road to reach the camp, where accommodation is available. Due to absence of planned tour circuits for viewing animals, tourist vehicles crisscross all over and follow animals wherever they are. This repeated off-road driving has led to vegetation degradation and development of multiple tracks that have contributed to destroying vegetation. Ndegwa Mundia \& Murayama (2009) made a corresponding observation in a wildlife sanctuary in East Africa.

The observed changes of LULC in NGR were characterized by the increase in agricultural area at the expense of natural vegetation (shrub savanna and woodland). These dynamics attest to the ongoing deforestation in southern Burkina Faso. This conversion was also noticed elsewhere in West Africa (Badjana et al., 2015; Houessou et al., 2013; Zoungrana et al., 2015).

The results of the landscape metrics analysis provide a global understanding of key trends of vegetation structure.

Changes in land cover were related to modification of spatial patterns, as confirmed by landscape- and class-level metrics. Landscape-level metrics revealed absence of fragmentation processes and a decline of habitat fragments between 1984 and 2002. This 
Dimobe K., Goetze D., Ouédraogo A., Forkuor G., Wala K., Porembski S., Thiombiano A.: Spatio-temporal dynamics in land use and habitat fragmentation within a protected area dedicated to tourism in a Sudanian savanna of West Africa

does not indicate a reduction in human activities such as agricultural activities, but could rather be the result of previously isolated patches becoming connected. From 2002 to 2013, however, metrics indicated the presence of smaller and more isolated patches resulting from ongoing fragmentation, corresponding to results from Benin (Mama et al., 2013) and D. R. Congo (Bamba et al., 2008). The class-level metrics analysis indicated that the increase in the number of patches was related to the reduction of the largest patch index (LPI), with concomitant fragmentation and habitat loss (Echeverría et al., 2006). Landscape fragmentation is not a random process, but follows a specific pattern (Echeverría et al., 2012; Lindenmayer \& Fischer, 2006; Lindenmayer \& Fischer, 2013).

Gallery forest metrics between 2002 and 2013 showed that, although the number of patches increased, the LPI did not decrease in size. The Euclidean Nearest Neighbor Distance (ENN_MN) among patches decreased while the Patch Cohesion Index (COHESION) increased, suggesting that also the connectivity of gallery forest patches had increased. It follows that the NP increase resulted from the appearance of new small patches rather than from fragmentation of older patches, showing an effect of natural regeneration.

The results achieved with calculations of landscape metrics do match those from LULC change detection. Other authors such as Bamba et al. (2008) and Mama et al. (2013) who have worked in D. R. Congo and Benin, respectively, have also made a similar observation. They reported that degradation of forest and savanna ecosystems is characterized by a high degree of fragmentation.

Up to 1984 the landscape was dominated by near-natural habitats of shrub and tree savannas. Farms were usually located outside the protected area. In contrast, by 2013 the area of agricultural land had expanded greatly into land previously occupied by shrub and tree savannas within the NGR. This result corresponds to findings by Bamba et al. (2008) from D. R. Congo pertaining to the period 1960 to 2005. The expansion of agricultural land into the protected area can be linked to management shortcomings after 2002 due to an insufficient number of forest agents, lack of adequate means to monitor the ranch, and lack of awareness to educate local people regarding the value and protection of natural resources in the NGR.

\section{CONCLUSION}

Results of this study have provided evidence of recent vegetation dynamics in the NGR showing trends of habitat degradation, corresponding to many savanna areas in Africa and beyond. In general, this is a known consequence of rapid population growth while attaining limitations in natural resource provision also due to global change effects. What makes this study peculiar is the presence of notable populations of wild savanna animals and a notable number of tourists coming to this site for viewing or hunting them. As, according to the original management goals and purpose of existence of the reserve, both savanna fauna and wildlife tourism are to be maintained and sustained in a sustainable way, adaptation of land use by local inhabitants is the main option for avoiding further degradation of vegetation and thus of the existence basis of animals worth seeing and of tourism. This situation highlights an urgent need for better sensitizing and educating local people about the benefits that an intact savanna reserve provides to them via animals and wildlife tourism that generate employment and revenues for them, substituting needed income from higher yields they otherwise would attempt to achieve while contributing to further ecological degradation. Creating this awareness and readiness in local populations to respect nature conservation and 
sustainable ways of land use only works when the alternative, i.e. livelihood improvement from nature conservation and tourism, is becoming part of villagers' reality. Therefore, local authorities and the reserve management essentially need to support public education and provide incentives and revenues related to conservation of the reserve and tourism.

At the same time, populations of ecologically influential animal species such as elephants within the NGR need to be managed to regulate their destructive impact on habitats, e.g. by facilitating their migration towards existing adjacent habitats with adapted high carrying capacity through establishing migration corridors. In addition, tourist movements are to be regulated and directed correspondingly according to a field visit concept to be set up for the different seasons. This would be an asset for the conservation of wildlife and habitats, and the maintenance of tourism and ecosystem balance.

Results from this study provide crucial aspects for sustainability concepts over large areas of West African savannas comprising protected areas.

This study used mono-temporal images for the LULC classifications. Future studies will compare mono-temporal and multi-temporal LULC classifications as well as their combination with ancillary data in order to improve classification accuracy. Furthermore, the introduction of Sentinel-2 is expected to improve the LULC classifications and analysis on landscape metrics.

\section{ACKNOWLEDGEMENTS}

This work was conducted in the WASCAL (West African Science Service Center on Climate Change and Adapted Land Use) project and supported by the German Federal Ministry of Education and Research (BMBF). We thank the field assistants and local people who helped in data collection. We would also like to thank the two anonymous reviewers for their helpful comments.

\section{REFERENCES}

Alqurashi, A. F.\& Kumar, L. (2014). Land use and land cover change detection in the Saudi Arabian desert cities of Makkah and Al-Taif using satellite data. Advances in Remote Sensing 3:106-119.

Amahowe, O., Ouedraogo, M. \& Lougbegnon, O. (2012). Analyse spatio-temporelle de la faune et des pressions anthropiques dans le ranch de Gibier de Nazinga au Burkina Faso. International Journal of Biological and Chemical Sciences 6:613-627.

Anderson, J. R., Hardy, E.E., Roach, J.T. \& Witmer, R.E. (1976). A Land Use and Land Cover Classification System for Use with Remote Sensor Data USGS Professional Paper 964, Sioux Falls, SD, USA.

Aubreville, A. (1957). Nomenclature of African vegetation types at Yangambi. Bois et Forêt des Tropiques 51:23-27.

Badjana, H.M., Helmschrot, J., Selsam, P., Wala, K., Flügel, W.A., Afouda, A. \& Akpagana, K. (2015). Land cover changes assessment using object-based image analysis in the Binah River watershed (Togo and Benin). Earth and Space Science 2: 403-416. DOI: 10.1002/2014EA000083.Received

Bamba, I., Mama, A., Neuba, D.F., Koffi, K.J., Traore, D., Visser, M., Sinsin, B., Lejoly, J. \& Bogaert, J. (2008). Influence des actions anthropiques sur la dynamique spatio-temporelle de l'occupation du sol dans la province du Bas-Congo (RD Congo). Sciences \& Nature 5: 49-60 
Barima, Y.S.S, Barbier, N., Bamba, I., Traoré, D., Lejoly, J., \& Bogaert, J. (2009). Dynamique paysagère en milieu de transition forêt-savane ivoirienne. Bois et Forêt des Tropiques 299: 15-25

Baskent, E.Z., \& Kadiogullari, A.I. (2007). Spatial and temporal dynamics of land use pattern in Turkey: a case study in Inegöl. Landscape Urban Plan 81:316-327.

Bottomley, B. (1998). Mapping rural land use \& land cover change In Carroll County, Arkansas utilizing multi-temporal Landsat Thematic Mapper satellite imagery. Unpublished doctoral dissertation, University of Arkansas.

Bouché, P., Lungren, C.G., \& Hien, B. (2004). Recensement aérien total de la faune dans l'Ecosystème naturel Po-Nazinga-Sissili (PONASI). Burkina Faso Programme CITESMIKE, Rapport definitif.

Bouché, P., Lungren, C.G., Hien, B., Addison, D., Boafu, F., Daho, V., Darko, T., Doamba, B., Gansaoré, G. \& Geddes, C. (2003). Recensement aérien total de la faune dans l'Ecosystème naturel Po-Nazinga-Sissili (PONASI). Burkina Faso. Programme CITESMIKE, Rapport definitif.

Bracchetti, L., Carotenuto, L., \& Catorci, A. (2012). Land-cover changes in a remote area of central Apennines (Italy) and management directions. Landscape Urban Plan 104:157-170.

Chambers, R. (1986). Sustainable Livelihoods, Institute of Development Studies. University of Susses, Susse tr

Congalton, RG. \& Green, K. (2008). Assessing the accuracy of remotely sensed data: principles and practices. CRC press

Cunningham, S.A. (2000). Effects of habitat fragmentation on the reproductive ecology of four plant species in mallee woodland. Conservation Biology 14:758-768

Dekker, A. (1985). Carte de paysage de la région du Ranch de Gibier de Nazinga, Burkina Faso. PNUD/FAO. DP/BKF/82/008

del Castillo, E.M., García-Martin, A., Aladrén, L.A.L., \& de Luis, M. (2015). Evaluation of forest cover change using remote sensing techniques and landscape metrics in Moncayo Natural Park (Spain). Applied Geography 62:247-255

Dimobe, K., Ouédraogo, A., Soma, S., Goetze, D., Porembski, S. \& Thiombiano, A. (2015). Identification of driving factors of land degradation and deforestation in the Wildlife Reserve of Bontioli (Burkina Faso, West Africa). Global Ecology and Conservation 4:559-571

Echeverría, C., Coomes, D., Salas, J., Rey-Benayas, J.M., Lara, A., Newton. (2006). Rapid deforestation and fragmentation of Chilean temperate forests. Biological conservation 130:481-494.

Echeverría, C., Newton, A., Nahuelhual, L., Coomes, D., Rey-Benayas, J.M. (2012). How landscapes change: Integration of spatial patterns and human processes in temperate landscapes of southern Chile. Applied Geography 32:822-831.

Forkuor, G., Conrad, C., Thiel, M., Ullmann, T., Zoungrana, E. (2014). Integration of optical and Synthetic Aperture Radar imagery for improving crop mapping in Northwestern Benin, West Africa. Remote Sensing 6:6472-6499.

Gowda, J.H., Kitzberger, T., Premoli, A. (2012). Landscape responses to a century of land use along the northern Patagonian forest-steppe transition. Plant Ecology 213:259-272. 
Guinko, S. (1984). La végétation de la Haute-Volta. Unpublished doctoral dissertation,Université de Bordeaux III.

Guldemond, R., Van Aarde, R. (2007). The impact of elephants on plants and their community variables in South Africa's Maputaland. African Journal of Ecology 45:327-335. Hema, E.M., Barnes, R.F., Guenda, W. (2011). Distribution of savannah elephants (Loxodonta africana africana Blumenbach 1797) within Nazinga game ranch, Southern Burkina Faso. African Journal of Ecology 49:141-149

Hema, E.M., Barnes, R.F., Guenda, W. (2013). Elephants or Excrement? Comparison of the Power of Two Survey Methods for Elephants in West African Savanna. Environment and Pollution 2:14-26.

Hien, B. (2005). Factors affecting variability in the distribution of elephants at Nazinga Game Ranch (Burkina Faso, West Africa). Unpublished doctoral dissertation, University of South Dakota State.

Hien, B.M., Jenks, J.A., Klaver, R.W.,\& Wicks, Z. (2007). Determinants of elephant distribution at Nazinga Game Ranch, Burkina Faso. Pachyderm 42:70-80.

Houessou, L.G., Teka, O., Toko, I., Lykke, A.M. \& Sinsin, B. (2013). Land Use and Land-Cover Change at "W" Biosphere Reserve and Its Surroundings Areas in Benin Republic (West Africa). Environment and Natural Resources Research 3: 87-101. DOI: 10.5539/enrr.v3n2p87

Ikpa, T., Dera, B., \& Jande, J. (2009). Biodiversity conservation: Why local inhabitants destroy habitat in protected areas. Science World Journal 4 (4):22-27.

Jachmann, H. \& Croes, T. (1991). Effects of browsing by elephants on the Combretum/Terminalia woodland at the Nazinga game ranch, Burkina Faso, West Africa. Biological Conservation 57:13-24.

Lambin, E.F., Geist, H.J., \& Lepers, E. (2003). Dynamics of land-use and land-cover change in tropical regions. Annual review of environment and resources 28:205-241

Landman, M., Kerley, G., \& Schoeman, D. (2008). Relevance of elephant herbivory as a threat to Important Plants in the Addo Elephant National Park, South Africa. Journal of Zoology 274:51-58

Lewis, M.M. (1998). Numeric classification as an aid to spectral mapping of vegetation communities. Plant Ecology 136: 133

Lillesand, T.M, Kiefer, R.W. \& Chipman, J.W. (2004). Remote sensing and image interpretation. John Wiley \& Sons Ltd

Lindenmayer, D.B., \& Fischer, J. (2006). Habitat fragmentation and landscape change: an ecological and conservation synthesis. Island Press

Lindenmayer, D.B.,\& Fischer, J. (2013). Habitat fragmentation and landscape change: an ecological and conservation synthesis. Island Press

Lu, D., Mausel, P., Brondizio, E., \& Moran, E. (2004). Change detection techniques. International Journal of Remote Sensing 25:2365-2401

Lunetta, R.S., \& Elvidge, C.D. (1999). Remote sensing change detection: environmental monitoring methods and applications. Taylor \& Francis Ltd.

Mama, A., Sinsin, B., De Cannière, C., \& Bogaert, J. (2013). Anthropisation et dynamique des paysages en zone soudanienne au nord du Bénin. Tropicultura 31:78-88. 
McGarigal, K., Cushman, S., \& Ene, E. (2012). FRAGSTATS v4: Spatial Pattern Analysis Program for Categorical and Continuous Maps. University of Massachusetts, Amherst Computer software program produced by the authors at the Uni-versity of Massachusetts

McGarigal, K., Cushman, S.A., Neel, M.C., \& Ene, E. (2002). FRAGSTATS: spatial pattern analysis program for categorical maps. University of Massachusetts, Amherst Computer software program produced by the authors at the Uni-versity of Massachusetts

Meyer, W.B. \& Turner, B. (1994). Changes in land use and land cover: a global perspective vol 4. Cambridge University Press.

Nagendra, H., Munroe, D.K. \& Southworth, J. (2004). From pattern to process: landscape fragmentation and the analysis of land use/land cover change. Agriculture, Ecosystems \& Environment 101:111-115

Nasseri, N.A., McBrayer, L.D. \& Schulte, B.A. (2011). The impact of tree modification by African elephant (Loxodonta africana) on herpetofaunal species richness in northern Tanzania. African Journal of Ecology 49:133-140.

Ndegwa Mundia, C. \& Murayama, Y. (2009). Analysis of land use/cover changes and animal population dynamics in a wildlife sanctuary in East Africa. Remote Sensing 1:952-970

Ojima, D., Galvin, K. \& Turner, B. (1994). The global impact of land-use change. BioScience 44:300-304

Ouédraogo, M. (2005). Régulation de la dynamique des populations de buffles (Syncerus caffer Sparrman) et de Waterbucks (Kobus ellipsiprymnus Ogilby) et moyens de gestion à mettre en ouvre pour préserver l'équilibre des communautés végétales dans le ranch de Nazinga (Burkina Faso). Unpublished doctoral dissertation, University of Gembloux.

Pôças, I., Cunha, M., Marcal, A.R. \& Pereira, L.S. (2011). An evaluation of changes in a mountainous rural landscape of Northeast Portugal using remotely sensed data. Landscape Urban Plan 101:253-261.

Portier, B. \& Lungren, C. (2007). La faune et le ranching au Burkina Faso (Nazinga). Gembloux, Belgique: Les Presses agronomiques de Gembloux:33-44.

Portier, B. (2000). Liste exhaustive des espèces d'oiseaux recensées au Ranch de Gibier de Nazinga Projet de Valorisation Scientifique du Ranch de Nazinga. Rapport interne, Ouagadougou, Burkina Faso.

Reid, R.S., Kruska, R.L., Muthui, N., Taye, A., Wotton, S., Wilson, C.J. \& Mulatu, W. (2000). Land-use and land-cover dynamics in response to changes in climatic, biological and socio-political forces: the case of southwestern Ethiopia. Landscape Ecology 15:339-355

Swanepoel, C. \& Swanepoel, S. (1986). Baobab damage by elephant in the middle Zambezi, Valley, Zimbabwe. African Journal of Ecology 24:129-132.

Teixido, A.L., Quintanilla, L.G., Carreno, F. \& Gutierrez, D. (2010). Impacts of changes in land use and fragmentation patterns on Atlantic coastal forests in northern Spain. Journal of Environmental Management 91:879-886

Terzioğlu, S., Başkent, E.Z. \& Kadıŏulları, A.İ. (2009). Monitoring forest structure at landscape level: a case study of Scots pine forest in NE Turkey. Environmental monitoring and assessment 152:71-81. 
Toko, I.M., Touré, F., Imorou, I.T. \& Sinsin, B. (2012). Indices de structures spatiales des îlots de forêts denses dans la région des Monts Kouffé. VertigO-la revue électronique en sciences de l'environnement 12

Tscharntke, T., Klein, A.M., Kruess, A., Steffan-Dewenter, I. \& Thies, C. (2005). Landscape perspectives on agricultural intensification and biodiversity-ecosystem service management. Ecology letters 8:857-874.

Vila Subirós, J., Llausàs Pascual, A., Varga Linde, D. \& Ribas Palom, A. (2006). Conceptos y métodos fundamentales en ecología del paisaje (landscape ecology). Una interpretación desde la geografía. Documents d'anàlisi geogràfica:151-166

Yameogo, U. (1999). Contribution à l'étude du feu comme outil de gestion des aires protégées. Cas des feux tardifs dans le Ranch de Gibier de Nazinga Burkina Faso. Unpublished master dissertation, Université Paris I, IV, VI.

Zoungrana, B.J.B., Conrad, C., Amekudzi, L.K., Thiel, M., Da, E.D., Forkuor, G. \& Löw, F. (2015). Multi-Temporal Landsat Images and Ancillary Data for Land Use/Cover Change (LULCC) Detection in the Southwest of Burkina Faso, West Africa. Remote Sensing 7: 12076-12102 